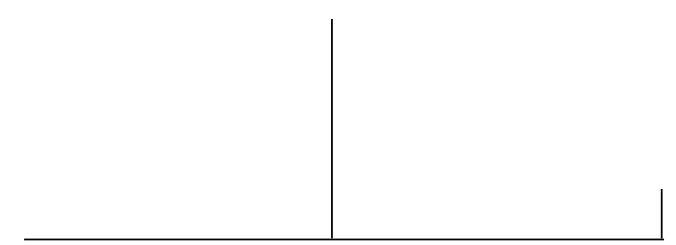

Rev. Latinoam. Psicopat. Fund., São Paulo, v. 15, n. 3, p. 615-617, setembro 2012

Cientistas e feiticeiros: uma abordagem crítica da psiquiatria atual Claudio Lyra Bastos

Rio de Janeiro: Revinter, 2012, 308 págs.

\title{
Entre a ciência e a feitiçaria
}

Luiz Carlos Marques

O que seria o charlatanismo? E a feitiçaria? O que é doença? Questões como essas se tornam cada vez mais presentes numa época em que certas formas das chamadas "medicinas alternativas" chegam a receber status de prática oficial na saúde pública.

O título curioso do livro atrai a atenção para um texto em que se compara a visão fragmentada da psiquiatria atual com a produção gráfica de esquizofrênicos, como Bispo do Rosário, ou o pregador americano Howard Finster. Sua ideia central é a de que a nossa incapacidade de pensar o todo em diversos níveis de causalidade nos impede de escapar das eternas dicotomias e dos apelos maniqueístas.

A crise que atinge a psiquiatria não se refere apenas às ações sociais, mas se estende à psicoterapia e à psicofarmacoterapia. Boa parte dos psicotrópicos hoje em dia é prescrita por médicos não psiquiatras, como cardiologistas, pediatras e reumatologistas, que pouco 
conhecimento tem dessa prática. Paradoxalmente, em todas essas áreas do saber, é exatamente dos psiquiatras que surgem os elementos paradigmáticos, os caminhos e as figuras de destaque na produção de conhecimento e de maior repercussão na sua expressão pública. Da mesma forma, nenhuma outra especialidade ou profissão jamais conseguiu atender integral e explicitamente às demandas pessoais, familiares e sociais dos pacientes. São contradições notáveis, às quais não se pode deixar de prestar atenção e tentar compreender.

$\mathrm{O}$ autor dedica-se à tarefa de expor essas contradições por meio de um enfoque, por assim dizer, antropológico, na medida em que as busca nos elementos da cultura. Usa também os seus trinta anos de atividade clínica e forense diária para fundamentar uma crítica que não vem do gabinete, mas da prática real.

Mesmo voltado para o âmbito psiquiátrico e universitário em geral, o texto pode ser entendido, sem maiores dificuldades, por qualquer leitor culto que tenha o seu interesse despertado pelo tema. A clareza de expressão, a ausência de jargões e a intenção do autor em definir objetivamente todo trecho mais complexo torna simples a tarefa do leitor. Assim são enfocadas as três vertentes básicas da psiquiatria: a biológica, a psicológica e a social.

A falta da perspectiva fenomenológica teve como consequência inevitável a absorção da psicopatologia pelas ideologias específicas de cada momento ou local. Desta forma surgiram o biologismo, o psicanalismo, o sociologismo etc. Destaca que até mesmo a chamada etnopsiquiatria, cuja proposta era essencialmente crítica, tornou-se ela própria um baluarte do relativismo exacerbado, estritamente acadêmico e desvinculado da realidade prática. As querelas entre as facções baseiam-se, na verdade, em falsas questões, disputas artificiais pouco mais que retóricas, uma vez que seus sectários só discutem mesmo entre si, num campo anteriormente definido e controlado.

Sustenta que a ideia de transdisciplinaridade, conceituada por Piaget em meados do século passado, jamais foi realmente levada a sério, nem na clínica nem na academia. Permaneceu um termo retórico e desprovido de significado prático, que é usado quando se levantam temas como complexidade e redes causais. Tornou-se pouco mais que um bordão, reiterado periodicamente. Meio século se passou e as disciplinas continuam sem dialogar entre si. Em 1925, Abraham Flexner, o criador do moderno ensino médico acadêmico americano, já se queixava da ausência de uma formação mais adequada dos estudantes. De forma inversa ao publish or perish atual, ele prescrevia: "Think much, publish little". A burocratização da academia hoje em dia criou um frenesi publicatório que bem poderia ser descrito invertendo o conselho de Flexner: Publish much, think little.

A antiguidade e a perenidade da psiquiatria, desde a praticada pelos sacerdotes hindus ou egípcios há dezenas de séculos - utilizando psicofármacos e psicoterapia - até a dos dias de hoje, é o ponto de partida. Nenhuma alternativa jamais 
vai substituir a visão integrada que a sua prática exige. Se a multiplicidade ideológica a torna fragmentária, ela se reconstrói diariamente na sua ação. Tornar a psiquiatria mais coerente a partir da sua prática é o leitmotiv do texto.

\section{Luiz Carlos Marques}

Psiquiatra, atendo no Hospital Universitário Antonio Pedro e em sua clínica particular (Instituto Fluminense de Saúde Mental.

Rua Guilherme Briggs, 51 - São Domingos

24210-175 Niterói, RJ

e-mail: luizcarlmarq@uol.com.br 